\title{
The Study of the Opinions of the Teachers Working in the Field of Special Education towards their Level of Burnout and Life Satisfaction (TRNC Sample)
}

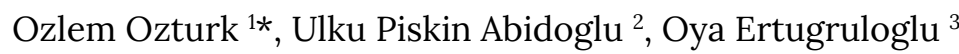

\author{
${ }^{1}$ Karabuk Mehmet Mescier Private Education Job Application Center, Karabuk, TURKEY \\ ${ }^{2}$ Cyprus International University, Faculty of Education, Department of Special Education, Haspolat, CYPRUS \\ ${ }^{3}$ Vice-Chancellor, American University of Cyprus, Nicosia, CYPRUS \\ *Corresponding Author: ozlem198076@hotmail.com
}

Citation: Ozturk, O., Abidoglu, U. P., \& Ertugruloglu, O. (2017). The Study of the Opinions of the Teachers Working in the Field of Special Education towards their Level of Burnout and Life Satisfaction (TRNC Sample). Mediterranean Journal of Social \& Behavioral Research, 1(23), 73-82. https://doi.org/10.30935/mjosbr/8380

\begin{abstract}
The aim of this study is to examine the perceptions of special education teachers on their burnout levels and life satisfaction. In this research, Maswlach Burnout Scale (MBS) and Life Satisfaction Scale (LSS) were used. The population of the study involves 67 special education teachers ( 35 female and 32 male teachers) who are employed in elementary schools governed by the Ministry of National Education System in Turkish Republic of Northern Cyprus. These schools have special education centers and resource rooms. The findings showed that there are significant differences between the burnout levels of the teachers in terms of their age, their status of working and not working with a specific group of people with disability. The findings also revealed significant differences between their life satisfaction and their field of study. In addition, a perfect negative correlation was found between the participants' scores of MPS and LSS.
\end{abstract}

Keywords: special education, burnout, life satistaction

Received: 13 Jun. 2017 • Accepted: 2 Sep. 2017

\section{INTRODUCTION}

Education is a complicated system consisting numerous elements. The factors such as teacher, student, parent or guardian and environment cover a significant part of the education system. In this system, the elements have to be rigidly tied to each other like a chain ring. If one of the rings in the system breaks, this means that the system would be damaged and problems which are irrepairable or even impossible to be recovered would emerge in the education. As the individuals changing and developing the behaviours of students, teachers are the irreplaceable elements of the education system. Teachers' power of influencing the other elements is very high as they form the key elements of the system. This situation significantly increases the expectations wanted from the teachers. Teachers have a crucial role in the development of society, raising qualified people, the socialization of individuals and preparing them to community life, and handing down the culture and values of the society to the new generations. For this reason, teachers are accepted as the architectures shaping the individuals. The fact that the society is generated by the individuals means that teachers shaping a person directly contribute to the formation of the society (Gunduz, 2006, p. 17).
It was expressed that teachers interact not only with students but also with families, directors and the entire society. This situation causes teachers to be loaded with much more duty and responsibility. Especially teachers working with children with special needs need to act with more selflessly and have more toleration and patience. However the situations such as inadequacy in teaching conditions and receiving inappropriate demands throughout their professional lives cause them to be stressed which results in various reactions and consequences. Some of them try to cope with the problems and stress they experience and the others suffer from a burnout based on different factors.

Burnout is a condition which can often be encountered among individuals having personal contact with people and interacting physically or emotionally with other people as a part of their jobs. Burnout can be observed in every profession group where a "human" is at the focus point of the job. Doctors, nurses, psychologists, bankers, teachers are some of them. Especially, the burnout is highly possible to be seen among teachers since they have a responsibility to make a significant contribution to the development of the individuals. In professions where people are served, the responsibilities of the employees increase and the exhaustion in profession is more likely to be experienced. Changing working conditions and working 
environments also provide grounds for exhaustion among people. (Akçamete, Kaner, \& Sucuoglu, 2001, p. 1-5).

The concept of burnout was firstly defined by Freudenberger in the early 1970s. Freudenberger has defined burnout as "loss of strength and energy as a consequnce of failure, exhaustion, overloading or exhaustion in people's internal resources as a result of unmet demands." On the other hand, Maslach has defined burnout as "a psychological resistance to the problems and the resulting causes of stress experienced by the individual at the workplace." In addition to his definition, Maslach has also developed a scale predicting the concept of burnout and this is currently being used often in almost every group of profession. The intensity of the emotional processes, the need to constantly engage with people and the need for interaction, and the fact that the personality traits directly influence work causes more stress in professions demanding contact with people. The inability to cope with the stress experienced and consequently feeling of the stress level at the upper levels causes burnout (Yegin, 2014, p. 316-317).

Education is one of the fields which the interaction and communication with people are experienced at the highest level and consists of an emotional interaction between teachers, the key element of the education, and other individuals within the system. As a result of covering an emotional interaction, the sense of responsibility felt towards the humans involve much more stress in comparison with the one felt towards the objects, and thus, it is more likely to be observed that the employees working in the field of education suffer from a burnout. Especially teachers practicing in the field of special education need to show a greater sensitivity as they are in a constant communication both with the parents and students in different problem groups. This situation exhausts the teachers at times and can cause them to experience a severe burnout if they do not refresh and improve themselves.

The sense of well-being of a person is shown among the significant identifier of health. It is known that humans are satisfied with their lives and remain in a happy state as long as they have the sense of well-being. Satisfaction with life is defined as humans' act of coming to a conclusion by comparing what they have with their expectations. In other words, it is described as the opinions individuals reach about their lives as a result of comparing their desires with the things they have. When studying the relevant body of literature, it is observed that the satisfaction with life is collected in three categories: in the first group, the satisfaction with life "is defined based on the external criteria such as well-being, virtue and divineness"; in the second group, an individual's answers to the question of "what causes a person to evaluate his or her own life positively?" are accepted as the source of his or her satisfaction with life. Lastly, daily life is used as the baseline in the third group. The dominant idea is that if an individual has more positive emotions than the negative ones in his daily life, he equally obtains pleasure and happiness out of life, therefore, he also reaches a condition where he is satisfied with his life (Acar Arasan, 2010, p. 7-8).

The satisfaction with life closely associated with individuals' subjective well-being varies among individuals. It generally means being pleased with life. It is not a situational evaluation but rather the condition of being satisfied with the entire living living. The factors influencing the satisfaction with life can be arranged as an individual's situation of finding the life meaningful, being happy with the daily life, and feeling economically insecure and physically and mentally well. In short, the satisfaction with life is the general attitude of a person towards the life (Gülcan, 2014, p. 21). It is observed in the research conducted that there is an inverse proportion between burnout and satisfaction with life as a person would not be able to enjoy his life and be happy as he suffers from burnout. For this reason, as the burnout increases, the satisfaction with life would be decreasing.

Research on the burnout of teachers have been quite common in Turkey in the recent years. The research generally focusses on the occupational burnout. Despite the considerable number of studies focusing on the burnout of teachers, the number of scientific studies analysing the burnout of teachers practicing in the field of special education is limited. It is observed that the relationship between demographic variables such as age, gender and marital status are examined in the research conducted on the burnout of special education teachers. In addition to this, the working hours of the teachers, the academic area they have obtained a degree on, their professional titles, the type of schools they are working at, their financial conditions and the inabilities of the students they provide education are also studied. The other dimension of the studies carried out on the burnout of the special education teachers are formed by the relational research comparing the special education teachers in terms of factors such as the directors and general education teachers.

The objective of this research is to analyse the opinions on the level of burnout and satisfaction with life which are acquired from the special education teachers working in the primary schools with a private support room and the special education institutions run by the government under the umbrella of the Directorate of Primary Education Department within the Ministry of National Education during the academic year of 2014-2015. In accordance with this purpose, answers will be sought for the following sub-problems:

1. What is the extent of the opinions about the level of burnout and condition of satisfaction with life of special education teachers working in TRNC's governmental institutions run by the Directorate of Primary Education Department within Ministry of National Education?

2. Do the levels of burnout and satisfactions with life of special education teachers working in TRNC's governmental institutions run by the Directorate of Primary Education Department within Ministry of National Education differ according to the variables of gender, age, marital status, period of duty, the academic area they have obtained a degree on, whether or not they have worked in a specific disability group (mentally handicapped, hearing-impaired, physically handicapped, autistics, visually handicapped people and others with different disabilities), level of education and income?

3. Is there any relationship between the levels of burnout and satisfaction with life of special education teachers working in TRNC's governmental institutions run by the Primary Education Department of the Ministry of National Education?

\section{METHOD}

\section{The Method of Research and the Sample Group}

A descriptive and relational study has been conducted and a screening model has been used due to the fact that this research is carried out with the purpose of identifying the levels of burnout and satisfaction with life of the teachers working within the field of special 
education in primary schools with a private support room and the special education institutions run by the government under the umbrella of the Directorate of Primary Education Department within the Ministry of National Education and determining the correlation between the two variables. Questionnaires are collected from the participants by the researchers and the statistical analyses of the acquired data have been performed with SPSS (Version 18.0).

The sample group of the research includes teachers practicing in the field of special education. For this reason, it has been aimed to involve the teachers working within the field of special education in primary schools with a private support room and the special education institutions run by the government under the umbrella of the Directorate of Primary Education Department within TRNC Ministry of National Education in this study. Except the two teachers who refused to participate in the study among the 69 , the data were collected from the remaining 67 teachers. $35(52.2 \%)$ of the participants are female and $32(47.8 \%)$ are male. Besides, it has been found that $76.6 \%$ of the teachers are married and $25.4 \%$ are single. It can be observed when analysing the age range that $25.4 \%$ of them are between the ages of 20 $29,35.8 \%$ are between $30-39$ and $38.8 \%$ are 39 and older. While the ratio of the ones graduated from the schools for special education is $59.7 \%$, graduates from other fields consist of $40.3 \%$ of the participants. It is examined in terms of the period of duty of the teachers that $65.7 \%$ of them are those working for 11 years or more in this field. $4.5 \%$ of the participants have been working for 1-5 years and 29.9\% for 6-10 years. The group of disability teachers work mostly consist of mentally handicapped children by $86.6 \%$. While $64.2 \%$, of the teachers received education at the level of undergraduate degree, only $34.3 \%$ of them had postgraduate degrees. $50.7 \%$ of the teachers consider their incomes sufficient and $32.8 \%$ find it moderately sufficient, however, it is considered as insufficient $16.4 \%$.

\section{Data Collection Tools}

\section{Maslach Burnout Inventory (MBI)}

The inventory was developed by Maslach and Jackson in 1981. Preapplication of the Maslach Burnout Inventory translated into Turkish by Ergin (1993) was performed on a group of 235 people (doctors, nurses, polices, lawyers, etc.) and some changes were made on the scale in the light of the analysis of the data collected from the group. The answer options consisting of seven stages which are "never, a few times a year, once a month, a few times a month, once a week, a few times a week, and every day" were changed and reduced to five stages as they are not compatible with the Turkish culture.

The scale consisting of 22 articles, five-staged answer options and three sub-dimensions have also been used in this research. These subdimensions are emotional burnout, desensitization, and the extent of personal success, respectively. The inventory does not follow a total scoring. In the analysis of the literature, it is found out that different scorings of the scale have been applied. The ratings are observed to be generally implemented as (0-4) or (1-5). The work of Ergin (1993) was used as the foundation of this study and rating of (1-5) was preferred because of its ease of calculation. The option of "never" in the answers is evaluated with the rating of 1 , "very rare" option is with 2, "sometimes" option is with 3 , "mostly" option is with 4 and "always" option is with 5 .

The emotional burnout and desensitization dimension of the Maslach burnout inventory is calculated in this way, however, a change was made in calculation when approaching the dimension of personal success, because, while the dimensions of emotional burnout and desensitization are constituted by the negative expressions, the dimension of personal success is formed by the positive ones. This is the reason of calculating the dimension of personal success reversely in the study. For instance, "I achieved numerous considerable success in this job” is an article in the personal success dimension of the scale. This article is formed by a positive expression. Therefore, the rating of 5 is given when opting never among the answers, 4 is marked for opting very rare and 1 is for opting always. In conclusion, the burnout is considered to be high as the ratings increase, as in the other dimensions (Ergin, 2001, p. 49-51).

The reliability of MBI is calculated with two methods. The first one is the calculation of internal consistency for each subdimension $(n=552)$. The second is the test-retest reliability $(n=$ 99). Reliability coefficients concerning the unique form of MBI have been calculated as $.83(.90)$ for the internal consistency for emotional burnout, .83 (82.) for the test-retest, $.65(.79)$ for the internal consistency for desensitization, $.72(.60)$ for the testretest, $.72(.71)$ for the internal consistency for personal success and .67 (.80) for the test-retest (Oruc, 2007, p. 46-47).

It is observed that the construct validity of the scale is approached by analysing the factor structure. Varimax rotation was applied as in the unique form of the scale and three main factors were obtained" (Ergin, 1993). Whether the answers were influenced by the social desirability or not was studied in the second analysis on the validity. The comparison of Kozan's (1983) scale of social desirability with the measurement of burnout has shown that the answers were moderately affected by the social desirability. Coefficients of correlation the measurement of burnout shows with the scale of social desirability are as follows: Emotional Burnout: -.32, Desensitization: -.48, Personal Success: .36. (Karahan, 2008, p. 73).

In this research, the Cronbach's Alpha Coefficients of the Maslach Burnout Inventory have been calculated as 0.758 for the total scale, 0.731 for the emotional burnout, 0.555 for the sub-dimension of desensitization and 0.556 for the sub-dimension of personal success. In this sense, it is observed that the coefficients of the total scale of Maslach and the emotional burnout have a considerable reliability, while the reliability coefficients of the desensitization from the sub-dimensions of the Maslach Burnout Inventory and the sub-dimensions of personal success are at a moderate level. Taking these results into consideration, it is possible to state that Maslach Burnout Inventory is reliable for TRNC. It is observed in the literature review carried out that the scale has been frequently used in TRNC in the recent years. Based on the information received from the academics in the department of educational administration and inspection it is possible to indicate that the use of the scale in this research is valid.

\section{Satisfaction with life scale (SWLS)}

"Satisfaction with Life Scale" developed by Diener and his friends (1985) was used in the research to measure teacher's satisfaction with life. "Yetim (1993) who applied the scale to the Turkish population found the reliability of the scale very high $(\mathrm{Alpha}=86)$. Test-retest reliability is acquired as 73 . Cetinkaya (2004) found the convergence 
Table 1. The evaluation of the scores obtained from MBI and the sub-scales of MBI according to the gender variable

\begin{tabular}{|c|c|c|c|c|c|c|c|}
\hline Dimension & Variable & Category & $\mathbf{n}$ & $\mathbf{x}^{-}$ & s.s. & $\mathbf{t}$ & $\mathbf{p}$ \\
\hline \multirow{2}{*}{ EB } & \multirow{2}{*}{ Gender } & Female & 35 & 1.89 & 0.65 & \multirow{2}{*}{1.42} & \multirow{2}{*}{0.161} \\
\hline & & Male & 32 & 2.08 & 0.41 & & \\
\hline \multirow{2}{*}{ D } & \multirow{2}{*}{ Gender } & Female & 35 & 1.34 & 0.50 & \multirow{2}{*}{0.79} & \multirow{2}{*}{0.433} \\
\hline & & Male & 32 & 1.52 & 0.42 & & \\
\hline \multirow{2}{*}{ PS } & \multirow{2}{*}{ Gender } & Female & 35 & 2.24 & 3.94 & \multirow{2}{*}{0.44} & \multirow{2}{*}{0.661} \\
\hline & & Male & 32 & 2.29 & 2.84 & & \\
\hline \multirow{2}{*}{ MBI } & \multirow{2}{*}{ Gender } & Female & 35 & 1.91 & 0.43 & \multirow{2}{*}{1.30} & \multirow{2}{*}{0.197} \\
\hline & & Male & 32 & 2.03 & 0.26 & & \\
\hline
\end{tabular}

Table 2. The evaluation of the scores obtained from MBI and the sub-scales of MBI according to the marital status variable

\begin{tabular}{|c|c|c|c|c|c|c|c|}
\hline Dimension & Variable & Category & $\mathbf{n}$ & $\mathbf{x}^{-}$ & s.s. & $\mathbf{t}$ & $\mathbf{p}$ \\
\hline \multirow{2}{*}{ EB } & \multirow{2}{*}{ Marital Status } & Married & 50 & 2.01 & 0.47 & \multirow{2}{*}{0.73} & \multirow{2}{*}{0.471} \\
\hline & & Single & 17 & 1.90 & 0.75 & & \\
\hline \multirow{2}{*}{ D } & \multirow{2}{*}{ Marital Status } & Married & 50 & 1.50 & 0.44 & \multirow{2}{*}{0.91} & \multirow{2}{*}{0.366} \\
\hline & & Single & 17 & 1.38 & 0.53 & & \\
\hline \multirow{2}{*}{ PS } & \multirow{2}{*}{ Marital Status } & Married & 50 & 2.25 & 3.55 & \multirow{2}{*}{0.53} & \multirow{2}{*}{0.601} \\
\hline & & Single & 17 & 2.31 & 3.14 & & \\
\hline MBI & Marital Status & Single & 17 & 1.93 & 0.45 & 0.49 & 0.626 \\
\hline
\end{tabular}

validity of the Satisfaction with Life Scale as 33 and 40 for two different scales." (Aydemir, 2013, p. 38).

Cronbach's Alpha Coefficient of the satisfaction with life scale was calculated as 0.819 in this research. It can be indicated according to this result that the satisfaction with life scale is reliable for TRNC. Based on the information about the validity of the satisfaction with life scale received from the statistic experts working in different universities It is possible to state that this scale is considered as valid in TRNC.

\section{Personal Information Form}

The aim of the personal information form created by the researcher was to obtain some demographic and professional information about the participant teachers. While the gender, age and marital status of the teachers are included in the demographic information, their period of duty, the academic area they have obtained the degree on, whether or not they have worked in a specific disability group, education level and income generating from their jobs are collected under the professional information.

\section{FINDINGS AND INTERPRETATION}

Findings of the Statistical Analyses Conducted Between the Variables and the Scores Obtained from the Maslach Burnout Inventory and Sub-Scales

The "Maslach burnout inventory" and opinions on its subdimensions of "emotional burnout, desensitization and personal success" acquired from the teachers working in the primary schools with a private support room and the special education institutions run by the government under the umbrella of the Directorate of Primary Education Department within the TRNC Ministry of National Education, has been evaluated and interpreted under this heading.

Analysis findings of the scores obtained from Maslach burnout inventory and Maslach burnout sub-scales according to gender

T-test was used to analyse whether or not the total scores of MBI and MBI sub-scales differs significantly according to gender. In Table 1 the results of the t-test analysis of the differences between the gender variable and the total scores obtained from MBI and the sub-scales of MBI are demonstrated.

In the analysis results presented in Table 1 it is observed that within the total score of MBI a significant difference was not discovered in accordance with the gender variable $(t(65)=0.197, p>0,05)$. The similar results were acquired in the analyses conducted with the scores from MBI sub-scales. Examining the analysis by gender conducted on PS, D and EB sub-scale scores, a significant differentiation according to the gender variable are not observed in any of the three dimensions PS, $(t(65)=0,661, \quad p>0,05) ; \quad D,(t(65)=0.433, \quad p>0,05) ; \quad E B,(t(65)=0.161$, $\mathrm{p}>0,05)$. The findings show that there is no significant difference between the gender variable and the level of burnout of the teachers working in the field of special education in TRNC.

Analysis findings of the scores obtained from Maslach burnout inventory and Maslach burnout sub-scales according to marital status

T-test was used to analyse whether or not the total scores of MBI and MBI sub-scales differs significantly according to marital status. In Table 2 the results of the $t$-test analysis of the total scores obtained from MBI and the sub-scales of MBI and the marital status variable are demonstrated.

In the analysis results presented in Table 2 it is observed that within the total score of MBI a significant difference was not found in accordance with the marital status variable $(t(65)=0.626, p>0.05)$. No significant difference was observed according to the analysis results conducted with the scores obtained from the sub-scales of MBI. Examining the analysis by marital status conducted on PS, D and EB sub-scale scores, a significant differentiation according to the marital status variable are not found in any of the dimensions $P S,(t(65)=0.601$, $\mathrm{p}>0.05) ; \mathrm{D},(\mathrm{t}(65)=0.366, \mathrm{p}>0.05)$; $\mathrm{EB},(\mathrm{t}(65)=0.471, \mathrm{p}>0.05)$.

Analysis findings of the scores obtained from Maslach burnout inventory and Maslach burnout sub-scales according to the period of duty

T-test was used to analyse whether or not the total scores of MBI and MBI sub-scales differs significantly according to the period of duty. In Table 3 the results of the analysis are demonstrated. 
Table 3. The evaluation of the scores obtained from MBI and the sub-scales of MBI according to the period of duty variable

\begin{tabular}{|c|c|c|c|c|c|c|c|}
\hline Dimension & Variable & Category & $\mathbf{n}$ & $\mathbf{x}^{-}$ & s.s. & $\mathbf{t}$ & $\mathbf{p}$ \\
\hline \multirow{2}{*}{ EB } & \multirow{2}{*}{ Period of Office } & $1-10$ years & 23 & 2.18 & 0.48 & \multirow{2}{*}{1.47} & \multirow{2}{*}{0.148} \\
\hline & & 11 years and more & 44 & 2.05 & 0.58 & & \\
\hline \multirow{2}{*}{ D } & \multirow{2}{*}{ Period of Office } & $1-10$ years & 23 & 1.48 & 0.86 & \multirow{2}{*}{0.12} & \multirow{2}{*}{0.907} \\
\hline & & 11 years and more & 44 & 1.47 & 0.48 & & \\
\hline \multirow{2}{*}{ PS } & \multirow{2}{*}{ Period of Office } & $1-10$ years & 23 & 2.27 & 3.30 & \multirow{2}{*}{0.04} & \multirow{2}{*}{0.966} \\
\hline & & 11 years and more & 44 & 2.26 & 3.54 & & \\
\hline MBI & Period of Office & 11 years and more & 44 & 2.00 & 0.39 & 0.85 & 0.399 \\
\hline
\end{tabular}

Table 4. The evaluation of the scores obtained from MBI and the sub-scales of MBI according to the academic area of the degree obtained variable

\begin{tabular}{|c|c|c|c|c|c|c|c|}
\hline Dimension & Variable & Category & $\mathbf{n}$ & $\mathbf{x}^{-}$ & s.s. & $\mathbf{t}$ & $\mathbf{p}$ \\
\hline \multirow{2}{*}{ EB } & \multirow{2}{*}{$\begin{array}{l}\text { the academic area of } \\
\text { the degree obtained }\end{array}$} & Special Education & 40 & 1.92 & 0.60 & \multirow{2}{*}{1.06} & \multirow{2}{*}{0.294} \\
\hline & & Other & 27 & 2.07 & 0.47 & & \\
\hline \multirow{2}{*}{ D } & \multirow{2}{*}{$\begin{array}{l}\text { the academic area of } \\
\text { the degree obtained }\end{array}$} & Special Education & 40 & 1.42 & 0.44 & \multirow{2}{*}{1.12} & \multirow{2}{*}{0.266} \\
\hline & & Other & 27 & 1.55 & 0.49 & & \\
\hline \multirow{2}{*}{ PS } & \multirow{2}{*}{$\begin{array}{l}\text { the academic area of } \\
\text { the degree obtained }\end{array}$} & Special Education & 40 & 2.25 & 3.85 & \multirow{2}{*}{0.36} & \multirow{2}{*}{0.721} \\
\hline & & Other & 27 & 2.29 & 2.77 & & \\
\hline MBI & $\begin{array}{l}\text { the academic area of } \\
\text { the degree obtained }\end{array}$ & Other & 27 & 2.03 & 0.33 & 1.14 & 0.259 \\
\hline
\end{tabular}

Table 5. The evaluation of the scores obtained from MBI and the sub-scales of MBI according to the education level variable

\begin{tabular}{|c|c|c|c|c|c|c|c|}
\hline Dimension & Variable & Category & $\mathbf{n}$ & $\mathbf{x}^{-}$ & s.s. & $\mathbf{t}$ & $\mathbf{p}$ \\
\hline \multirow{2}{*}{ EB } & \multirow{2}{*}{ Education level } & Undergraduate level and lower & 44 & 2.04 & 0.56 & \multirow{2}{*}{1.09} & \multirow{2}{*}{0.278} \\
\hline & & Postgraduate & 23 & 2.21 & 0.53 & & \\
\hline \multirow{2}{*}{$\mathbf{D}$} & \multirow{2}{*}{ Education level } & Undergraduate level and lower & 44 & 1.49 & 0.50 & \multirow{2}{*}{0.43} & \multirow{2}{*}{0.670} \\
\hline & & $\begin{array}{c}\text { Postgraduate } \\
\end{array}$ & 23 & 1.44 & 0.40 & & \\
\hline \multirow{2}{*}{ PS } & \multirow{2}{*}{ Education level } & Undergraduate level and lower & 44 & 2.33 & 3.27 & \multirow{2}{*}{1.86} & \multirow{2}{*}{0.067} \\
\hline & & Postgraduate & 23 & 1.26 & 3.55 & & \\
\hline MBI & Education level & Postgraduate & 23 & 1.87 & 0.35 & 1.61 & 0.113 \\
\hline
\end{tabular}

The results of the analysis illustrates that there is no significant difference according to the period of duty variable in the total score of $\operatorname{MBI}(t(65)=0.399, p>0.05)$. Besides, no significant difference was found in accordance with the analysis results conducted with the scores obtained from the sub-scales of MBI. PS, $(\mathrm{t}(65)=0.966, \mathrm{p}>0.05)$; $\mathrm{D}$, $(\mathrm{t}(65)=0.907, \mathrm{p}>0.05) ; \mathrm{EB},(\mathrm{t}(65)=0.148, \mathrm{p}>0.05)$.

Analysis findings of the scores obtained from Maslach burnout inventory and Maslach burnout sub-scales according to the academic area of the degree obtained

T-test was used to analyse whether or not the total scores of MBI and MBI sub-scales differs significantly according to the academic area of the degree obtained or not. In Table 4 the results of the analysis are demonstrated.

According to Table 4, no significant differentiation was detected in any category of the academic area of the degree obtained variable and the scores obtained from MBI and sub-scales of MBI. The total score of $\operatorname{MBI}(\mathrm{t}(65)=0.259, \mathrm{p}>0.05) ; \mathrm{PS},(\mathrm{t}(65)=0.721, \mathrm{p}>0.05) ; \mathrm{D},(\mathrm{t}(65)=0.266$, $\mathrm{p}>0.05)$; $\mathrm{EB},(\mathrm{t}(65)=0.294, \mathrm{p}>0.05)$.

Analysis findings of the scores obtained from Maslach burnout inventory and Maslach burnout sub-scales according to the education level

The result of the T-test conducted with the purpose of analysing whether or not the total scores of MBI and MBI sub-scales differs significantly according to the education level is demonstrated in Table 5.
The analysis results in Table 5 illustrate that MBI is $(t(65)=0.113$, $\mathrm{p}>0.05)$ in the dimension of total score, $(\mathrm{t}(65)=0.067, \mathrm{p}>0.05)$ in the dimension of PS, $(\mathrm{t}(65)=0.670, \mathrm{p}>0.05)$ in the dimension of $\mathrm{D}$ and $(t(65)=0.278, p>0.05)$ in the dimension of EB. This shows that the scores obtained from MBI and the sub-scales of MBI do not differ at a significant level according to the education level variable.

Analysis findings of the scores obtained from Maslach burnout inventory and Maslach burnout sub-scales according to whether or not the participant has worked in specific disability groups

T-test was used to analyse whether or not the total scores of MBI and MBI sub-scales differed according to whether or not the participant has worked in specific disability groups. Some differentiations were detected in the sub-dimensions of personal success and desensitization. It was observed that the sub-scale score of teachers working with visually handicapped people is statistically significantly lower than the teachers not working with visually handicapped people $(\mathrm{t}(65)=2.08$; $\mathrm{p}=0.048$ ). Similarly, the sub-scale scores of desensitization of the special education teachers working with hearing impaired individuals are found to be statistically significantly lower than their colleagues not working with hearing impaired individuals $(\mathrm{t}(65)=3.18$; $\mathrm{p}=0.002)$. The sub-scale scores of desensitization of the teachers working with physically handicapped people $(\mathrm{t}(65)=2.64 ; \mathrm{p}=0.010)$ and special education teachers working with people in the other disability group $(t(65)=2.76 ; \mathrm{p}=0.007)$ are observed to be statistically significantly lower than their colleagues not working in any of these two disability groups. 
Table 6. Evaluation of the scores obtained from MBI and MBI subscales according to the age variable

\begin{tabular}{|c|c|c|c|c|c|c|c|}
\hline Dimension & Variable & Category & $\mathbf{n}$ & $\mathbf{x}^{-}$ & s.s. & $\mathbf{f}$ & $\mathbf{p}$ \\
\hline \multirow{3}{*}{ EB } & \multirow{3}{*}{ Age } & 20-29 & 17 & 1.79 & 0.49 & \multirow{3}{*}{3.27} & \multirow{3}{*}{0.044} \\
\hline & & $30-39$ & 24 & 2.20 & 0.64 & & \\
\hline & & 39 and over & 26 & 1.91 & 0.45 & & \\
\hline \multirow{3}{*}{ D } & \multirow{3}{*}{ Age } & $20-29$ & 17 & 1.44 & 2.31 & \multirow{3}{*}{0.05} & \multirow{3}{*}{0.953} \\
\hline & & 30-39 & 24 & 1.49 & 2.41 & & \\
\hline & & 39 and over & 26 & 1.48 & 2.39 & & \\
\hline \multirow[t]{2}{*}{ PS } & \multirow[t]{2}{*}{ Age } & $30-39$ & 24 & 2.34 & 0.43 & \multirow[t]{2}{*}{0.63} & \multirow[t]{2}{*}{0.538} \\
\hline & & 39 and over & 26 & 2.24 & 0.39 & & \\
\hline \multirow{3}{*}{ MBI } & \multirow{3}{*}{ Age } & $20-29$ & 17 & 1.86 & 0.28 & \multirow{3}{*}{2.27} & \multirow{3}{*}{0.112} \\
\hline & & $30-39$ & 24 & 2.09 & 0.43 & & \\
\hline & & 39 and over & 26 & 1.93 & 0.32 & & \\
\hline
\end{tabular}

Table 7. Evaluation of the scores obtained from MBI and MBI subscales according to the income variable

\begin{tabular}{|c|c|c|c|c|c|c|c|}
\hline Dimension & Variable & Category & $\mathbf{n}$ & $\mathbf{x}^{-}$ & s.s. & f & $\mathbf{p}$ \\
\hline \multirow{3}{*}{ EB } & \multirow{3}{*}{ In come } & Sufficient & 34 & 1.88 & 0.49 & \multirow{3}{*}{1.15} & \multirow{3}{*}{0.323} \\
\hline & & Moderately Sufficient & 22 & 2.08 & 0.64 & & \\
\hline & & Insufficient & 11 & 2.10 & 0.56 & & \\
\hline \multirow{3}{*}{ D } & \multirow{3}{*}{ Income } & Sufficient & 34 & 1.41 & 2.03 & \multirow{3}{*}{0.73} & \multirow{3}{*}{0.488} \\
\hline & & Moderately Sufficient & 22 & 1.52 & 2.30 & & \\
\hline & & Insufficient & 11 & 1.58 & 3.27 & & \\
\hline \multirow{3}{*}{ PS } & \multirow{3}{*}{ Income } & Sufficient & 34 & 2.23 & 0.45 & \multirow{3}{*}{0.20} & \multirow{3}{*}{0.818} \\
\hline & & Moderately Sufficient & 22 & 2.28 & 0.41 & & \\
\hline & & Insufficient & 11 & 2.33 & 0.43 & & \\
\hline \multirow{3}{*}{ MBI } & \multirow{3}{*}{ Income } & Sufficient & 34 & 1.90 & 0.33 & \multirow{3}{*}{1.20} & \multirow{3}{*}{0.307} \\
\hline & & Moderately Sufficient & 22 & 2.03 & 0.38 & & \\
\hline & & Insufficient & 11 & 2.06 & 0.42 & & \\
\hline
\end{tabular}

Table 8. Evaluating the scores obtained from SWLS according to the gender variable

\begin{tabular}{|c|c|c|c|c|c|c|}
\hline Variable & Category & $\mathbf{n}$ & $\mathbf{x}^{-}$ & s.s. & $\mathbf{t}$ & $\mathbf{p}$ \\
\hline \multirow{2}{*}{ Gender } & Female & 35 & 5.22 & 1.04 & \multirow{2}{*}{1.96} & \multirow{2}{*}{0.540} \\
\hline & Male & 22 & 4.72 & 1.03 & & \\
\hline
\end{tabular}

Analysis findings of the scores obtained from Maslach burnout inventory and Maslach burnout sub-scales according to ago

ANOVA analysis was used to examine whether or not the total scores obtained from the MBI and MBI subscales differs significantly according to age. The ages of the participants are 20-29, 30-39 and 39 and over and was gathered in 3 groups. In Table 6 the results of the ANOVA analysis are given.

According to the analysis results in Table 6 no significant difference can be detected on the basis of MBI total score $(F(66)=2.27$; $\mathrm{p}=0.112)$, in the subdimension of desentisitation $(\mathrm{F}(66)=0.05 ; \mathrm{p}=0.953)$ and in the personal success subdimension $(\mathrm{F}(66)=0.63 ; \mathrm{p}=0.538)$. There is a significant differentiation seen in emotional burnout subdimension $(\mathrm{F}(66)=3.27 ; \mathrm{p}=0.044)$. Following statistical significance determined by ANOVA analysis, Tukey's HSD test was implemented as post hoc test in order to compare groups in pairs. Considering the Tukey's HSD test result, emotional burnout subscale scores of teachers between the age of 30-39 was found significantly higher than the teachers' between the age of 20-29 ( $\mathrm{p}=0.020)$.

Analysis findings of the scores obtained from Maslach burnout inventory and Maslach burnout subscales according to the income generating from the job

ANOVA analysis was used to examine whether or not the total scores of the MBI and MBI subscales differed according to income statuses. Income statuses of the participants are gathered in 3 groups as sufficient, moderately sufficient, and insufficient.

The results no significant difference can be detected on the basis of total MBI score $\left(\mathrm{F}_{(66)}=1.20 ; \mathrm{p}=0.307\right)$, in emotional burnout dimension $(\mathrm{F}(66)=1.15 ; \mathrm{p}=0.323)$, in desensitisation dimension $\quad(\mathrm{F}(66)=0.73$; $\mathrm{p}=0.488)$, in personal succes dimension $(\mathrm{F}(66)=0.20 ; \mathrm{p}=0.818)$.

Findings of Statistical Analyses Conducted Between the Scores Obtained from SWLS and Variables

Under this title, opinions of the teachers working at special education centres and in private support room of primary schools under the control of Directorate of Primary Education Department within the TRNC Ministry of National Education towards their satisfaction with life were evaluated and interpreted.

\section{Analysis findings of the scores obtained from the SWLS according to} gender

T-test was used in order to see whether or not the total score obtained from SWLS significantly differ according to gender. In Table 8 the t-test results between the SWLS and gender variable were given.

According to the results of the analysis, no significant difference was detected on the basis of the SWLS total score according to gender $(\mathrm{t}(65)=1.96 ; \mathrm{p}=0.540),(\mathrm{p}>0.05)$. 
Table 9. Evaluating the scores obtained from SWLS according to the marital status variable

\begin{tabular}{|c|c|c|c|c|c|c|}
\hline Variable & Category & $\mathbf{n}$ & $\mathbf{x}^{-}$ & s.s. & $\mathbf{t}$ & $\mathbf{p}$ \\
\hline \multirow{2}{*}{ Gender } & Married & 50 & 5.02 & 1.00 & \multirow{2}{*}{0.57} & \multirow{2}{*}{0.573} \\
\hline & Single & 17 & 4.85 & 1.23 & & \\
\hline
\end{tabular}

Table 10. Evaluating the scores obtained from SWLS according to period of duty variable

\begin{tabular}{|c|c|c|c|c|c|c|}
\hline Variable & Category & $\mathbf{n}$ & $\mathbf{x}^{-}$ & s.s. & $\mathbf{t}$ & $\mathbf{p}$ \\
\hline \multirow{2}{*}{ Period of duty } & 1-10 Years & 23 & 5.24 & 0.96 & \multirow{2}{*}{1.46} & \multirow{2}{*}{0.150} \\
\hline & 11 Years and Over & 44 & 4.85 & 1.09 & & \\
\hline
\end{tabular}

Table 11. Evaluating the scores obtained from SWLS according to the academic area of the degree obtained variable

\begin{tabular}{|c|c|c|c|c|c|c|}
\hline Variable & Category & $\mathbf{n}$ & $\mathbf{x}^{-}$ & s.s. & $\mathbf{t}$ & $\mathbf{p}$ \\
\hline \multirow{2}{*}{$\begin{array}{l}\text { Academic Area of } \\
\text { the Degree Obtained }\end{array}$} & Special Education & 40 & 5,20 & 0,96 & \multirow{2}{*}{2,07} & \multirow{2}{*}{0,042} \\
\hline & Other & 27 & 4,66 & 1,12 & & \\
\hline
\end{tabular}

Table 12. Evaluating the scores obtained from SWLS according to the level of education variable

\begin{tabular}{|c|c|c|c|c|c|c|}
\hline Variable & Category & $\mathbf{n}$ & $\mathbf{x}^{-}$ & s.s. & $\mathbf{t}$ & $\mathbf{p}$ \\
\hline \multirow{2}{*}{ Level of Education } & Undergraduate and high school & 44 & 4.87 & 1.06 & \multirow{2}{*}{1.21} & \multirow{2}{*}{0.232} \\
\hline & Postgraduate & 23 & 5.20 & 1.02 & & \\
\hline
\end{tabular}

Table 13. Evaluating the scores obtained from SWLS according to age variable

\begin{tabular}{|c|c|c|c|c|c|c|}
\hline Variable & Category & $\mathbf{n}$ & $\mathbf{x}^{-}$ & s.s. & f & $\mathbf{p}$ \\
\hline \multirow{3}{*}{ Age } & $20-29$ & 17 & 5.40 & 0.93 & \multirow{3}{*}{1.85} & \multirow{3}{*}{0.165} \\
\hline & $30-39$ & 24 & 4.79 & 1.19 & & \\
\hline & 39 and Over & 26 & 4.89 & 0.96 & & \\
\hline
\end{tabular}

\section{Analysis findings of the scores obtained from the SWLS according to} marital status

T-test was used in order to observe whether or not the total score obtained from SWLS significantly differ according to marital status. Findings were given in Table 9.

According to the results of the analysis, no significant difference between the SWLS total score and marital status variable were found $(\mathrm{t}(65)=0.57 ; \mathrm{p}=0.573),(\mathrm{p}>0.05)$.

Analysis findings of scores obtained from SWLS according to period of duty

In Table 10, the analyses and results were given by $\mathrm{T}$-test used in order to see whether or not the total score obtained from SWLS significantly differ according to period of duty.

According to the results of the analysis given in Table 10, no significant difference was detected on the basis of the SWLS total score according to the period of duty variable $(\mathrm{t}(65)=1.46 ; \mathrm{p}=0.150),(\mathrm{p}>0.05)$.

\section{Analysis findings of the scores obtained from SWLS according to the academic area of the degree obtained}

Obtained SWLS scores were analyzed with t-test according to the graduated field. T-test results were given in Table 11.

The results given in Table 11, satisfaction with life scores of the teachers graduated from special education areas were found statistically significantly higher than the teachers did not graduate from the special education field $(\mathrm{t}(65)=2.07 ; \mathrm{p}=0.042)$.

Analysis findings of the scores obtained from SWLS according to the level of education

In Table 12 T-test analysis was used to see whether or not there is a significant differentiation between the level of education variable and total SWLS score.
As seen in Table 12, there is no statistically significant difference between the life satisfaction and level of education $(t(65)=1.21 ; \mathrm{p}=0.232)$.

Analysis findings of the scores obtained from SWLS according to whether or not the participant has worked in specific disability groups

As a result of the t-test analysis, no significant differentiation was found between whether or not the participant has worked in specific disability groups and SWLS scores. Working with mentally disabled people $(\mathrm{t}(65)=0.38 ; 0.703)$, working with visually handicapped people $(t(65)=0.63 ; 0.532)$, working with hearing impaired people $(t(65)=0.63$; $0.532)$, working with physically handicapped people $(\mathrm{t}(65)=1.67 ; 0.100)$, working with autistic people $(\mathrm{t}(65)=0.43 ; 0.666)$ and working with other disabled people $(\mathrm{t}(65)=0.43 ; 0.672)$.

\section{Analysis findings of the scores obtained from SWLS according to age}

Comparison of opinions of teachers relating to age variables and life satisfaction scale was tested by using one way ANOVA analysis. ANOVA results were given in Table 13.

According to the analysis results of Table 13, no significant differentiation was detected on the basis of total score and age $(\mathrm{F}(66)=1.85 ; \mathrm{p}=0.165)$.

Analysis findings of scores obtained from SWLS by income generating from the job

ANOVA analysis method was used in order to determine the opinions of the teachers regarding income status and satisfaction with life scales. Income statuses of the participants are grouped as sufficient, moderately sufficient, and insufficient. Results of the analysis were given in Table 14.

According to the results of the analysis, a significant differentiation was detected between income status and satisfaction with life. Following the statistical significance found as a result of ANOVA analysis, Tukey's HSD test was implemented in order to compare the 
Table 14. Evaluating the scores obtained from SWLS according to income variable

\begin{tabular}{|c|c|c|c|c|c|c|}
\hline Variable & Category & $\mathbf{n}$ & $\mathbf{x}^{-}$ & s.s. & $\mathbf{f}$ & $\mathbf{p}$ \\
\hline \multirow{3}{*}{ Income } & Sufficient & 34 & 5.34 & 0.80 & \multirow{3}{*}{5.20} & \multirow{3}{*}{0.008} \\
\hline & Moderately Sufficient & 22 & 4.47 & 1.17 & & \\
\hline & Insufficient & 11 & 4.89 & 1.16 & & \\
\hline
\end{tabular}

$\Phi$ Statistically significant difference according to the sufficient income group

Table 15. Pearson Correlations Between all Subscales and Scales used in the Research $(n=67)$

\begin{tabular}{|c|c|c|c|c|c|c|}
\hline & & Emotional burnout & Desensitisation & Personal Success & Maslach Burnout & Life Satisfaction \\
\hline \multirow{2}{*}{ Emotional burnout } & $\mathrm{r}$ & 1 & & & & \\
\hline & $\mathrm{p}$ & & & & & \\
\hline \multirow{2}{*}{ Desensitisation } & $\mathrm{r}$ & 0.405 & 1 & & & \\
\hline & $\mathrm{p}$ & 0.001 & & & & \\
\hline \multirow{2}{*}{ Personal Success } & $\mathrm{r}$ & 0.316 & 0.130 & 1 & & \\
\hline & $\mathrm{p}$ & 0.009 & 0.294 & & & \\
\hline Maslach Burnout & $\mathrm{p}$ & 0.000 & 0.000 & 0.000 & & \\
\hline \multirow{2}{*}{ Life Satisfaction } & $\mathrm{r}$ & -0.489 & -0.144 & -0.252 & -0.454 & 1 \\
\hline & $\mathrm{p}$ & 0.000 & 0.244 & 0.040 & 0.000 & \\
\hline
\end{tabular}

groups in pairs. The result of the Tukey's HSD test determined that the opinions of the teachers' satisfaction with life towards their income statuses are sufficient is significantly higher than the teachers thinking that their income statuses are moderately sufficient $(F(66)=5.20$; $\mathrm{p}=0.008$ ).

Analysis Findings Regarding the Relationship Between the Scores Obtained from Maslach Burnout Invenstory and Maslach Burnout Subscales and Satisfaction with Life Scale

The relationship between the total scores obtained from MBI and MBI subscales and total scores obtained from SWLS was observed via correlation coefficient calculation analysis.

Results of the correlation analysis made in order to understand the possible statistical correlations among all scales and subscales observed in the research are shown in Table 15. Accordingly, it is seen that the score of the satisfaction with life scale has statistically significant negative correlation with Emotional Burnout $(r=-0.489 ; \mathrm{p}=0.000)$ and Personal Success $(\mathrm{r}=-0.252 ; \mathrm{p}=0.040)$ subscale scores which are from Maslach Burnout Inventory subscales. Similarly, the total score of Satisfaction with Life Scale and Maslach Burnout Inventory is found to have statistically significant negative correlation $(r=-0.454 ; \mathrm{p}=0.000)$. When these results are evaluated, it is found that when the burnouts related with emotional burnout and personal success and total burnout levels of the teachers working in special education fields increase, their life satisfactions decrease in return.

At the same time, the results of the correlation analysis among the subscales of the Maslach Burnout Inventory are presented in Table 15. While statistically significant correlation was being observed between Personal Success subscale and Desensitisation subscale $(r=-0.130$; $p>0.05$ ), statistically significant, positive correlations were observed among the scores of all other subscales and total scales appropriately $(\mathrm{p}<0,05)$. All scores tending to increase or decrease together were shown with significant correlations in consequence of the observation of scales and the total score of the burnout.

\section{RESULTS AND RECOMMENDATION}

The results shown by the findings obtained from the study in which the burnout levels and satisfaction with life levels of teachers working in special education schools were examined in terms of various variables (gender, marital status, term of duty, academic area of the degree optained, level of education, whether or not the participant has worked in specific disability groups, age, and income generating from the job) and interrelationships, can be summerized as follows;

1. Considering the results towards the relation between demographic and professional features with Emotional Burnout subscale no significant differentiations were found according to the gender, marital status, period of duty, academic area of the degree obtained, level of education, whether or not the participant has worked in specific disability group, age and income status generating from job data obtained from personal information form filled by the teachers. Significant differentiation was detected between emotional burnout and age. Teachers between the age range of 30-39 seem to have more burnout than teachers within the age range of 20-29.

2. Considering the results towards the correlation between demographic and professional features with Desensitisation subscale no significant differentiations were detected according to the gender, age, marital status, term of duty, academic area of degree obtained, level of education, and income status generating from job data obtained from personal information form filled by the teachers. However, some significant differentiations were detected among the group including the participants who have or have not worked with the specific disability groups. Desensitisation subscale scores of the teachers working with hearing impaired people is found statistically significantly lower than the teachers who are not working with hearing impaired people. In other words, teachers working with hearing impaired students face with burnout lower than the teachers who are working with other disability groups in desensitisation dimension. At the same time, the desensitisation subscale scores of the teachers working with physically handicapped people and special education teachers working with other disabled individuals were also found to be statistically significantly lower than their colleagues who are not working within this problem group. In other words, it has been determined that the teachers working with physically 
handicapped people and other disabled people experience a low level of burnout in the dimension of desensitisation.

3. Considering the results towards the correlation between demographic and Professional features with personal success dimension no significant differentiations were detected according to the gender, age, marital status, period of duty, academic area of the degree obtained, level of education, and income status generating from job data obtained from personal information form filled by the teachers. However, Burnout scores of the teachers working with visually impaired people is found statistically significantly lower than the teachers working with other disability groups in personal success dimension. This means that the teachers working with visually impaired people in the personal success dimension face with burnout lower than the teachers working in other disability groups.

4. Considering the results towards the correlation between demographic and professional features with Maslach burnout inventory, it has been detected that none of the independent variables examined in the research were found to have statistically significant differentiations between the categories.

5. Looking at the results towards the relation between the demographic and professional features on satisfaction with life, no significant differentiations were detected according to the data on gender, age, marital status, period of duty, academic area of the degree obtained, level of education, whether or not the participant has worked in specific disability group obtained from personal information form filled by the teachers. However, it has been detected that there is a significant differentiation between the academic area of the degree obtained and satisfaction with life. Satisfactions with life of the teachers' graduated from special education areas were found significantly higher than the teachers graduated from other departments. When looking at the corelation between the income status generating from the job and satisfaction with life it is observed that the life satisfaction of the teachers thinking that their income statuses are sufficient is significantly higher as compared to teachers' thinking that their income statuses are moderately sufficient.

6. Considering the correlation results among Maslach burnout inventory total score, emotional burnout, desensitisation and personal success subscales with satisfaction with life scale, it has been detected that there is a negative relation between emotional burnout and personal success subscales with satisfaction with life scale. At the same time, statistically negative correlation has been detected between the Maslach burnout inventory total scores and satisfaction with life. When these correlations evaluated, it is understood that as the emotional burnout of the special education teachers, the burnouts associated with personal success and the total burnout levels increase, the teachers' satisfactions with life decrease. As a result of the correlation analyses made with Maslach burnout inventory among all of the subscales, statistically significant positive correlations were observed among all other subscales and total scale scores as anticipated except for the relation between personal success and desensitisation subscales. With the observation of all the subscales and total scores related to burnout, that all the scores tend to increase or decrease together was shown with significant correlations.

Within the scope of obtained results, these reccommendations can be made in order to shed light onto new studies:

1. Organizing in-service trainings by TRNC Ministry of National Education towards increasing the professional development and fruitfulness of the teachers working in this area in the process, especially although they were not graduated from special education field and providing active participation of the teachers to these trainings are suggested.

2. Satisfaction with life is rather complicated and versatile variable. Individual's satisfaction with his/her job, happiness in his/her private life, harmony in his/her social life are among the important factors affecting the life satisfaction. Therefore, it is suggested to conduct studies examining the correlation different variables such as job satisfaction, social life harmony with life satisfaction.

3. This study examining the burnouts and teachers' satisfactions with life working in special education field in schools run by the Ministry of National Education in TRNC. It is suggested that subsequent studies should be carried out among different groups of teachers and especially examining their correlations between the teachers working in special education field.

4. In this study, teachers working in private support rooms in primary schools and special education centers were included. For the following studies it is recommended to include the teachers working in private support rooms in secondary schools and special institutions.

5. Investigating the causes burnout of the teachers within the age range of 30-39 working in special education field in TRNC with a qualitative study is suggested.

6. Conducting a qualitative study investigating the causes of burnout of the teachers working with different disability groups in TRNC is suggested.

\section{REFERENCES}

Acar Arasan, B. N. (2010). Akademisyenlerde yaşam doyumu iş doyumu ve mesleki tükenmișlik düzeylerinin belirlenmesine yönelik bir araștrma [A research on the determination of life satisfaction, job satisfaction and professional burnout levels among academicians] (Unpublished Masters Thesis), Usak University, Institute of Social Sciences, Turkey.

Akcamete, G., Kaner, S., \& Sucuoglu, B. (2001). Öğretmenlerde tükenmişlik iş doyumu ve kişilik [Burnout job satisfaction and personality in teachers]. Ankara, Turkey: Nobel Publishing \& Distribution.

Aydemir, H. (2013). Özel eğitim alannda çalşan öğretmenlerin tükenmişlik düzeyleri ve yaşam doyumlannn incelenmesi (Unpublished Masters Thesis), Abant Izzet Baysal University, Turkey, Institude of Education Sciences, Turkey.

Capa, Y., \& Cil, N. (2000). Öğretmen adaylarının öğretmenlik mesleğine yönelik tutumlarının farklı değişkenler açısından incelenmesi [Investigation of prospective teachers' attitudes towards teaching profession in terms of different variables]. H. Eğitim Fakültesi Dergisi, (18), 69-73. 
Ergin, C. (2001). Sağlık personelinin iş anlayışları ve tutumları araştırması. Sağhlk Dergisi, 3, 1-16. Retrieved from http://sbu.saglik. gov.tr/Ekutuphane/kitaplar/200702131615140saglikkitap.pdf

Gulcan, A. (2014). Genç yetişkinlerde iyimserliğin mutluluk ve yaşam doyumu üzerindeki etkisinin incelenmesi (Unpublished Masters Thesis). Fatih University, Institude of Social Sciences, Turkey.

Gunduz, B. (2006). Öğretmenlerde tükenmişliğin akılcı olmayan inançlar ile bazı meslek ve kişisel değişkenlere göre yordanması [Predicting burnout among teachers with irrational beliefs and some occupational and personal variables]. Türk Psikoloji ve Damşma Rehberlik dergisi, 3(26), 17-33.
Karahan, S. (2008). Özel eğitim okullannda çahşan eğitimcilerin öz yeterlik alglannın ve tükenmişlik düzeylerinin incelenmesi (Unpublished Masters Thesis), Marmara University, Institude of Education Sciences, Turkey.

Oruc, S. (2007). Özel eğitim alannda çahşan öğretmenlerin tükenmişlik düzeylerinin bazı değişkenler açıından incelenmesi (Adana ili örneği) (Unpublished Masters Thesis), Cukurova University, Institude of Social Sciences, Turkey.

Yegin, H. I. (2014). Din kültürü ve ahlâk bilgisi öğretmenlerinin tükenmişlik düzeyleri. Ekev Akademi Dergisi, 18(58), 315-332. Retrieved from http://www.ekevakademi.org/DergiTamDetay. aspx?ID $=211 \&$ Detay $=$ Ozet 